\title{
Success of Government E-Service Delivery: Does Satisfaction Matter?
}

\author{
Parmita Saha $^{1}$, Atanu Nath ${ }^{2}$, and Esmail Salehi-Sangari ${ }^{3}$ \\ ${ }^{1}$ Division of Industrial Marketing, E-Commerce, and Logistics, Luleå University of \\ Technology, Sweden \\ Department of Marketing, University of Surrey, Surrey, gu2 7xh, United Kingdom \\ p.saha@surrey.ac.uk \\ ${ }^{2}$ Department of Marketing, University of Surrey, Surrey, gu2 7xh, United Kingdom \\ a.nathasurrey.ac.uk \\ ${ }^{3}$ Division of Industrial Marketing and Entrepreneurship, Institute of Industrial Economy and \\ Organisation, The Royal Institute of Technology, Sweden \\ Division of Industrial Marketing, E-Commerce, and Logistics, Luleå University of \\ Technology, Sweden \\ ess@ltu.se
}

\begin{abstract}
For measuring e-government success a well-founded theory is important which can help governments to improve their services and identify how effectively public money is spent. We propose using citizen satisfaction as a measure of e-government success, as well as explore its relationships with e-government service quality. Three hypotheses have been formulated to test the model. For empirical estimation, the data used in this study was collected form Sweden. An online survey was conducted using systematic sampling among the municipalities in Sweden, 425 valid responses were received. The measures of each variables selected in this article were mainly adapted from related previous studies. Efficiency, privacy, responsiveness and web assistance were selected as e-service quality dimensions. Actual usages were measured by three items- Frequency of usage, Diversity of usages and Dependency. Confirmatory factor analyses were conducted to confirm the factor structures. The analysis shows that $43 \%$ of the variance among the factors of e-service quality, and usage is explained by citizen satisfaction. We found e-service quality has a relation with citizen satisfaction considering four dimensions of service quality. Efficiency, responsiveness and web assistance were found to be of more importance compared to privacy in determining eservice quality. Use was found to be positively and significantly related to citizen satisfaction. The results should contribute towards understanding of the key issues that influence citizens' needs and level of satisfaction with the tax services and help improve the service delivery process. Further research is suggested to explore other quality dimensions such as system and information quality.
\end{abstract}

Keywords: e-service quality, e-government success, satisfaction, e-tax. 


\section{Introduction}

Explosive growth of information and communication technology has had an impact on government activities, which allows for service delivery to the citizen electronically. The aim of this initiative is to deliver better services to the citizens and communities through information and communication technology (ICT), especially through the Internet (Blakeley and Matsuura, 2001). The emergence of e-government has molded the use of information and communications technology; and albeit with varying degrees of success, has transformed the public sector from being "inward looking and administration-focused" to becoming outward looking with a focus on service delivery (Connolly \& Bannister, 2008).

In order to provide e-government initiatives both national and regional governments have made serious investments in terms of resources, personnel and time and they believed that it will improve the quality of services of government for citizens. These indicate citizens could access a public service electronically; citizen could navigate through a number of public services and agencies electronically and access the most current information on services, regulations, procedures, forms, etc (Buckley 2003). Government organizational units are increasingly seeking ways to encourage citizens to use online modes of service delivery. To do so, it is imperative that such bodies take stock of the dimensions of website service excellence, to fully utilize the potential of such services and also to improve both its adoption by the citizenry as well as the level of satisfaction with public administration (Connolly \& Bannister, 2008).

For measuring e-government success a well-founded theory is important that can help governments to improve their services and identify how effectively public money is spent (Peters, Janssen \& Engers, 2004). Lihua \& Zheng (2005) identified egovernment performance as a dependent variable that includes service level to constituents and operational efficiency. It is important to have certain standards to measure the e-government success since transition from traditional government to egovernment remains complicated and difficult (Hu, Xiao, Pang, Xie, 2005).

Services literature has focused on the measurement of perceived quality, satisfaction of complex multi-service organizations (Peters, Janssen \& Engers, 2004). Bigné et al., (2003) identified the concepts of perceived quality and satisfactions are two of the fundamental pillars for evaluation for multi-service organization. They mentioned that measurement of perceived quality and satisfaction are more complex in multi-service organizations, where the customer has access to several services. It is necessary to take into consideration the overall perceived quality for measuring the quality of such integrated service. In private sector the bulk of service quality literature tends to originate in the profit-oriented contexts (Collins and Butler, 1995). Based on the variables identified by Parasuraman et al., (1988) which are tangibility, reliability, responsiveness, confidence and empathy, Bigné et al. (2003) used the scale to determine the perceived quality of the core services of hospitals, and universities. Buckley (2003) identified key issues in determining service quality in the public sector. Hazlett and Hill (2003) discussed the current level of government measurement. They mentioned the fact that government's two central aims, one being high quality customer service and the other being value-for money, could potentially be in conflict. In recent years, a number of researchers have focused their studies on 
the application of marketing and of the concepts of perceived quality and satisfaction to public services and in higher education (Bigné et al., 1997; Kanji and bin Tambi, 1999; and in health Bigné et al., 1997; Eckerlund et al., 2000). The assessment of service quality has been relatively less studied with respect to public services and most studies have focused on mainly two sectors health and education for assessing service quality. It is necessary to explore a different method of service quality evaluation of public services in the light of e-government success measurement (Ray \& Rao 2004).

Thus, the purpose of this study is to identify the factors affecting e-government success. Success factors are to be identified through applying service quality constructs which help assess the level of satisfaction of the recipients of such services.

\section{Theoretical Background}

The main elements of government E-service delivery include: electronic delivery of all appropriate government services; access to information about government services; electronic payment and a government-wide intranet for secure online communication. Web based e-government services can be defined as "the information and services provided to the public on government web sites (Wang et al., 2005). Improving customer satisfaction; development of strong relationship with customers and business partners; and the reduction of the service delivery costs are the main reasons for development of government e-services. For the delivery of government services the main strategy is to design a customer friendly website and to increase the collaboration between the government agencies for share information about the customer (Guo \& Raban, 2002).

\subsection{Citizen Satisfaction}

Government has the prospective to increase citizen satisfaction with government by utilizing the information and communication technology properly, specially the internet. This improved channel of communication ensures the accessibility and completeness of government information and service delivery in a more convenient way. Citizen satisfaction with e-government services is related with citizen's perception about online service convenience (transaction), reliability of the information (transparency) and engaged electronic communication (interactivity) (Welch, Hinnant \& Moon, 2004). Kelly \& Swindell (2002) defined Service out put as performance measurements and service outcomes as citizen satisfaction.

\subsection{Measuring E-Service Quality}

E-service quality has been studied less in the public sector (Buckley, 2003). Kaylor et al. (2001) highlight that existing research in the area of e-government focuses more on standards-based scenarios; in other words, an ideal scenario of service delivery. However, they point out that the realities that develop as the solutions are implemented are often different from an ideal situation; they state that looking only at standards does not provide us with enough insight into problems with specific functions and services as they are implemented in municipal Web sites. Based 
on the variables identified by Parasuraman et al. (1988) tangibility, reliability, responsiveness, confidence, and empathy, Bigné et al. (2003) used the scale to determine the perceived quality of the core services of hospitals and universities. Ray \& Rao (2004) identified service quality dimensions regarding a property tax payment system implemented by the municipal corporation of the city of Ahmedabad, Gujarat, India. They classified service quality dimensions into three broad categories. These are, service level expectations, Empowerment, and Anxiety reducing.

Zeithaml et al. (2000) developed e-SERVQUAL for measuring e-service quality. Through focus group interviews, they identified seven dimensions of online service quality: efficiency, reliability, fulfillment, privacy, responsiveness, compensation, and contact. They identified four dimensions, efficiency, reliability, fulfillment, and privacy, to form the core e-SERVQUAL scale that is used to measure customer perceptions of service quality delivered by online retailers. Parasuraman et al. (2005) developed an e-core service quality scale (E-S-QUAL) for examining Web site service quality in which 22 item scales were developed covering four dimensions to measure the service quality delivered by Web sites. These four dimensions are efficiency, fulfillment, system availability, and privacy. Connolly \& Bannister (2008) examined the dimensions of Web site service quality in the context of filing tax returns in Ireland using E-S-QUAL. Their study indicates the applicability of the SERVQUAL survey instrument in the context of government e-tax service, and it improved the understanding of the e-government service environment. We have chosen to conduct this study in Sweden since it is one of the leading countries in the Western world that has pro-actively engaged in incorporating e-governance strategies extensively. E-tax services run by Skatteverket is a primary example of such strategies being put in action. In Sweden every year approximately $6.5 \mathrm{~m}$ paper based version of tax forms are sent out among the Swedish citizen for tax filing purpose. Citizen can file tax through the Internet by using a "soft electronic ID, using a pin and pass word provided by the Tax board. Citizens also can use Tax board's telephone services or via sms. According to the Skatteverket's figures (Skatteverket pressmeddelande, 2009-05-06) over half the citizenry required to pay taxes are choosing to do so online. During the tax year 2008-2009, 3.9 million people filed their tax declarations electronically. This is a $9 \%$ increase over the previous year. 1.46 million, or $37 \%$ of online tax payers chose usage of a security code when filing taxes through the internet, whereas $24 \%$ chose to use a software based "e-legitimation" or electronic ID. This is in contrast to 2006-2007, when the total number of taxpayers who utilized electronic method of tax payment was $3,103,031$; out of which $1,657,848$ were women, and 1,445,183 were men. Thus, about $45 \%$ of the tax paying population used the electronic payment facilities, and 55\% used a paper based declaration. The number shows an increase of over half a million users who have started using an electronic method over the previous year.

\subsection{The Proposed Model and Research Hypotheses}

User satisfaction was identified as a significant measure of information system success (DeLone \& McLean 1992) and quality constructs and system used are identified as a critical success factors (Liu \& Arnett, 2000). We propose that Egovernment success can be determined by the citizen satisfaction, perceived service quality and usage of the system. 
"E-Service Quality is the extent to which a Web site facilitates efficient and effective shopping, purchasing and delivery of products and services" (Parasuraman et al., 2005). Based on this definition we defined e-government service quality as "the extent to which a website facilitates efficient and effective delivery of public services including information, communication, interaction, contracting and transaction to citizens, business partners, suppliers and those who are working in the government sector. A number of studies identified the determinant of satisfaction. Service quality has been found to be an important input to customer satisfaction (Caruana 2002). Cronin and Taylor (1992) originally hypothesized that satisfaction is an antecedent of service quality, their research with a multi industry sample showed, in a LISREL analysis, an opposite relationship. Service quality appears to be only one of the service factors contributing to customers' satisfaction judgments (Cronin and Taylor, 1992; Ruyter et al., 1997; Spreng and Mackoy, 1996). A number of academics such as Parasuraman et al. (1985, 1988); Grönroos (1984); Johnston (1997) and others have tried to identify key determinants by which a customer assesses service quality and consequently results in satisfaction or not. Roca et al., (2006) have also found the significant relationship between service quality and satisfaction in their study.

DeLone and MacLean (2004) included service quality in their original IS success model and they mentioned that service quality have a direct effect on user satisfaction and use. Use and user satisfaction are inter related with each other. To measure e-commerce system success Molla and Licker (2001) proposed customer satisfaction as a dependent variable and they proposed use has an impact on satisfaction. Researchers often measure breadth of use to measure the degree to which the system is used as a task. From the perspective of a system, breadth refers to the number of features used in the system (Burton-Jones and Straub 2004). Wang et al., (2007) proposed e-learning system success model. In their model they mention six factors that assess e-learing system success. According to their study service quality has a positive effect on use and satisfaction. Usage of the system has an impact on satisfaction and satisfaction has a relation with usage of the system. There are three aspects to e-service quality: user-focused, user satisfaction; outcomes (Buckley 2003).

Based on this discussion the following hypotheses have been formulated:

H1: Government e-service quality is positively related to user/citizen satisfaction.

$\mathrm{H} 2$ : Government e-service quality is positively related to actual usage

$\mathrm{H} 3$ : Actual usage is positively related to user/citizen satisfaction.

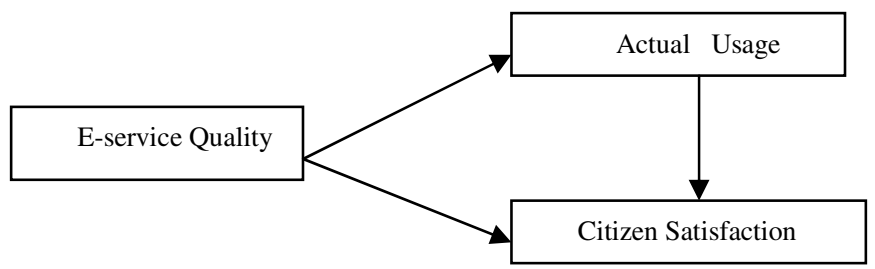

Fig. 1. Proposed model for the study 


\section{Empirical Methodology}

The data used to in this study were collected form Sweden. The questionnaire used in the survey was pre-tested prior to data collection. An online survey using a web based questionnaire with both Swedish and English versions was conducted using systematic sampling among the municipalities in Sweden. 425 valid responses were received. Criteria for selecting these respondent was familiarity with using the Swedish online tax payment system and familiar with the tax web site for getting different services, such as information search, filing tax return, registration etc. Efficiency, privacy, responsiveness and web assistance were selected as e-service quality dimension. All the items to measure these dimensions were selected from the previous research done by Zeithaml, Parasuraman, and Malhotra (2000, 2002, 2005); Xie, Tan \& Li (2002); Collier and Bienstock (2006).

Actual usages were measured by three items- Frequency of usage, Diversity of usages and Dependency. All the item were selected from previous studies done by Thompson, Higgins \& Howell (1991); Wang, Wang \& Shee (2007); Rai, Lang \& Welker (2002); Goodhue \& Thompson (1995). Five items were selected for measuring citizen satisfaction were derived from study conducted by Cronin, Brady \& Hult (2000); Luarn \& Lin (2003); Roca, Chiu \& Martinez (2006).

\section{Data Analysis}

In order to establish the internal consistency of the measurement instruments, reliability analysis was conducted by calculating coefficient alpha, also known as Cronbach's alpha to measure the internal consistency of the measurement scale. All the items are found to be reliable since the values are above the recommended level of 0.7. Cronbach's alpha of the scales Efficiency (.909) and satisfaction (.959) showed excellent internal consistency. Other three items- Web assistance (.873), privacy (.835) showed very good internal consistency of the scales. Coefficient alpha of Actual Usage (.756) and Responsiveness (.770) showed good internal consistency of the items. In order to further examine the factor structure of the 29- item instruments exploratory factor analysis was conducted. The factor loading of the item responsiveness 1 is low and less than 0.5 , it was removed from the list to measure eservice quality. Other two success factors: citizen satisfaction and actual use are clearly defined with high loading.

\subsection{Confirmatory Factor Analysis (CFA) to Confirm the Factor Structure}

Based on hypothesis testing, CFA is used to find out to which degree the different assumed variables measure a certain factor.

According to Janssens (2008) all the latent variable measures must have a high loading $(>.50)$ and must me significant (critical ratio= C.R. $=$ t-value $>1.96)$. In Table 1 , it shows that all of the unstandardized loadings (regression weights) differ significantly from zero. In the critical ratio column, all the values are over 1.96. Except one item priv 2 all the loadings are acceptable since all these are more than .50. In order to improve the model fit, item priv 2 was removed. 
Table 1. E-Service quality constructs

\begin{tabular}{|c|c|c|c|c|c|c|c|c|}
\hline Structural relation & \multicolumn{2}{|c|}{ Regression weight } & Standard error & \multicolumn{2}{|c|}{ Critical ratio } & \multicolumn{2}{|c|}{$\begin{array}{c}\text { Standardized } \\
\text { regression weights }\end{array}$} & \begin{tabular}{l}
\multicolumn{1}{c}{ squared } \\
multiple \\
correlation
\end{tabular} \\
\hline Eff $\leftarrow e S Q$ & & 1.000 & & & & & .718 & .515 \\
\hline Wass $\leftarrow$ eSQ & & 1.056 & .106 & & 9.971 & & .829 & .687 \\
\hline Priv $\leftarrow$ eSQ & & .291 & .088 & & 3.311 & & .198 & .039 \\
\hline Eff3 $\leftarrow$ eff & & 1.000 & & & & & .855 & .731 \\
\hline 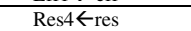 & & 1.000 & & & & & .666 & .443 \\
\hline 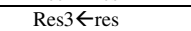 & & 1.148 & .079 & & 14.553 & & .884 & .781 \\
\hline Res $2 \leftarrow$ res & & 1.062 & .075 & & 14.220 & & .828 & .685 \\
\hline Wass $2 \leftarrow$ wass & & 1.000 & & & & & .870 & .756 \\
\hline Wass $1 \leftarrow$ wass & & 1.110 & .062 & & 17.971 & & .887 & .787 \\
\hline Model & RMSEA & CMIN/DF & GFI & AGFI & & FI & TLI & IFI \\
\hline Default model & .053 & 2.187 & .964 & .940 & & .982 & .975 & .982 \\
\hline Saturated model & & & 1.000 & & & 1.000 & & 1.000 \\
\hline $\begin{array}{l}\text { Independence } \\
\text { model }\end{array}$ & .334 & 48.271 & .381 & .257 & & .000 & .000 & .000 \\
\hline
\end{tabular}

There are different criteria to determine the overall fit of the models. The goodness of fit index (GFI) should be greater than .90 and the adjusted goodness of fit index (AGFI) preferably greater than .80. In this case GFI is .964 and AGFI .940 which means both values are greater than cut-off point. Two reliable indicators are the Tucker-Lewis Index (TLI) and Comparative fit index (CFI) which should preferably be greater than .90. In this case TLI and CFI are .975 and .982 which is more than acceptable level. The RMSEA value is .053 which indicates a good fit. $\mathrm{Hu}$ and Bentler (1999) place the cut-off value at .06, whereas Browne and Cudeck (1993) assert that values less than or equal to .05 indicate a good fit and values up to .08 indicate an acceptable fit.

Table 2. Satisfaction constructs

\begin{tabular}{|c|c|c|c|c|c|c|c|c|c|}
\hline $\begin{array}{l}\text { Structural } \\
\text { relation }\end{array}$ & $\begin{array}{l}\text { Regression } \\
\text { weight }\end{array}$ & \multicolumn{2}{|c|}{ Standard error } & \multicolumn{2}{|c|}{ Critical ratio } & \multicolumn{2}{|l|}{$\begin{array}{c}\text { Standardized } \\
\text { regression weights }\end{array}$} & \multicolumn{2}{|c|}{$\begin{array}{c}\text { squared } \\
\text { multiple correlation }\end{array}$} \\
\hline scsat $2 \leftarrow$ Csat & 1.000 & & & & & & .830 & \multicolumn{2}{|c|}{.689} \\
\hline Scsat $3 \leftarrow$ Csat & 1.121 & & .042 & & 26.479 & & .948 & \multicolumn{2}{|c|}{.899} \\
\hline Scsat $4 \leftarrow$ Csat & 1.021 & & .043 & & 23.701 & & .890 & \multicolumn{2}{|c|}{.792} \\
\hline Scsat $5 \leftarrow$ Csat & 1.087 & & .042 & & 26.141 & & .941 & \multicolumn{2}{|c|}{.886} \\
\hline \multicolumn{10}{|c|}{ Chi-square $=9.653, \mathrm{p}=.008$} \\
\hline Model & RMSEA & CMIN/DF & & GFI & AGFI & CFI & & TLI & IFI \\
\hline Default model & .095 & 4.827 & & .989 & .947 & .996 & & .987 & .996 \\
\hline Saturated model & & & & 1.000 & & 1.000 & & & 1.000 \\
\hline $\begin{array}{l}\text { Independence } \\
\text { model }\end{array}$ & .821 & 287.111 & & .334 & -.111 & .000 & & .000 & .000 \\
\hline
\end{tabular}

All standardized regression weight values are high, at over .70, and the critical ratios are over 1.96. Goodness of fit index (GFI) value is .989 , and average goodness of fit index (AGFI) is .947. Both values indicate very good model fit. The CFI (.996), TLI (.987), and IFI (.996) also indicate good model fit. The RMSEA (.095) and CMIN/DF (4.827) values are acceptable. 
Table 3. Model specification and hypothesis testing

\begin{tabular}{|c|c|c|c|c|c|c|c|c|c|}
\hline Structural relation & \begin{tabular}{|c|}
$\begin{array}{c}\text { Regression } \\
\text { weight }\end{array}$ \\
\end{tabular} & Standard error & & Criti & al ratio & $\begin{array}{c}\text { Standardized } \\
\text { egression weights } \\
\end{array}$ & & \multicolumn{2}{|c|}{$\begin{array}{l}\text { squared } \\
\text { multiple correlation }\end{array}$} \\
\hline $\mathrm{AU} \leftarrow \mathrm{eSQ}$ & 1.666 & \multicolumn{2}{|l|}{.549} & & 3.031 & \multicolumn{2}{|l|}{.314} & \multicolumn{2}{|r|}{.098} \\
\hline Eff $\leftarrow e S Q$ & & \multicolumn{2}{|r|}{.903} & \multicolumn{2}{|r|}{3.646} & \multicolumn{2}{|r|}{.755} & \multicolumn{2}{|c|}{.571} \\
\hline Priv $\leftarrow$ eSQ & $\begin{array}{l}.272 \\
1.000\end{array}$ & & & & & \multirow{2}{*}{\multicolumn{2}{|c|}{$\begin{array}{r}.217 \\
753\end{array}$}} & \multicolumn{2}{|c|}{.047} \\
\hline Res $\leftarrow$ eSQ & 2.767 & \multicolumn{2}{|r|}{.772} & \multicolumn{2}{|r|}{3.583} & \multirow{2}{*}{\multicolumn{2}{|c|}{$\begin{array}{l}.753 \\
795 \\
\end{array}$}} & \multicolumn{2}{|c|}{.567} \\
\hline Wass $\leftarrow e S Q$ & 3.153 & \multicolumn{2}{|r|}{865} & \multicolumn{2}{|r|}{3.647} & & & \multicolumn{2}{|c|}{.632} \\
\hline Csat $\leftarrow$ eSQ & \multirow{2}{*}{\begin{tabular}{r|}
1.852 \\
.401
\end{tabular}} & & .551 & \multicolumn{2}{|r|}{3.360} & \multicolumn{2}{|r|}{.374} & \multicolumn{2}{|c|}{.426} \\
\hline Csat $\leftarrow \mathrm{AU}$ & & & .051 & \multirow{2}{*}{\multicolumn{2}{|c|}{7.840}} & \multicolumn{2}{|r|}{.430} & & \\
\hline Eff $3 \leftarrow$ Eff & $\begin{array}{l}1.000 \\
1.068\end{array}$ & & & & & & .853 & .728 & \\
\hline Eff $2 \leftarrow$ Eff & 1.068 & & .048 & & 22.311 & & .883 & .779 & \\
\hline Eff1 $<$ Eff & 1.124 & & .053 & & 21.384 & & .852 & .726 & \\
\hline Priv4 $<$ Priv & 1.000 & & & & & & .809 & .655 & \\
\hline Priv3<Priv & 1.113 & & .068 & & 16.434 & & .924 & .853 & \\
\hline Priv1 $\leftarrow$ Priv & .728 & & .052 & & 14.021 & & .657 & .432 & \\
\hline $\operatorname{Res} 4 \leftarrow \operatorname{Res}$ & 1.000 & & & & & & .660 & .436 & \\
\hline Res $3 \leftarrow$ Res & 1.158 & & .080 & & 14.431 & & .885 & .783 & \\
\hline Res $2 \leftarrow \operatorname{Res}$ & 1.074 & & .076 & & 14.125 & & .831 & .690 & \\
\hline Wass $2 \leftarrow$ Wass & 1.000 & & & & & & .865 & .748 & \\
\hline Wass $1 \leftarrow$ Wass & 1.122 & & .063 & & 17.840 & & .892 & .795 & \\
\hline $\mathrm{Au} 1 \leftarrow \mathrm{Au}$ & 1.000 & & & & & & 825 & .680 & \\
\hline $\mathrm{Au} 2 \leftarrow \mathrm{Au}$ & .791 & & .067 & & 11.788 & & .692 & .479 & \\
\hline $\mathrm{Au} 3 \leftarrow \mathrm{Au}$ & .753 & & .070 & & 10.829 & & .611 & .373 & \\
\hline 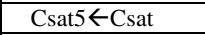 & .928 & & .035 & & 26.439 & & .938 & .881 & \\
\hline Csat $4 \leftarrow$ Csat & 1.033 & & .027 & & 38.504 & & .891 & .795 & \\
\hline Csat $3 \leftarrow$ Csat & .943 & & .030 & & 31.526 & & .948 & .898 & \\
\hline Csat $2 \leftarrow$ Csat & 1.000 & & & & & & .836 & .698 & \\
\hline & & Chi-square $=$ & $=423$. & $212, p$ & $=.000$ & & & & \\
\hline Model & RMSEA & \begin{tabular}{l|l}
$\mathrm{CMIN} / \mathrm{DF}$ & \\
\end{tabular} & GF & & AGFI & CFI & $\mathrm{TL}$ & & IFI \\
\hline Default model & .074 & 3.306 & & .907 & .875 & .942 & & .930 & .942 \\
\hline Saturated model & & & & 1.000 & & 1.000 & & & 1.000 \\
\hline $\begin{array}{l}\text { Independence } \\
\text { model }\end{array}$ & .279 & 34.031 & & .311 & .230 & .000 & & .000 & .000 \\
\hline
\end{tabular}

Model fit indicates a good fit. GFI is .907 which is good and greater than cut-off point and AGFI .875 which is also acceptable. Two reliable indicators are the TuckerLewis Index (TLI) and Comparative fit index (CFI) which should preferably be greater than .90. In this case TLI and CFI are .930 and .942 which is more than acceptable level. The RMSEA value is .074 which indicates acceptable fit. From the analysis, we can see that $43 \%$ of the variance among the factors of e-service quality, and usage is explained by citizen satisfaction. E-service quality is positively and significantly related to citizen satisfaction, with a path estimate of .37 , critical ratio of 3.360 , and significance at less than a $\mathrm{p}<0,001$ level. Therefore, the hypothesis is supported. The relationship between e-service quality and use is found to be significant, with the path value of .314 and a critical ratio of 3.031 . Thus, the hypothesis is accepted. Use is positively and significantly related to citizen satisfaction at significance level less than $<0.001$, with a path value .43 , and a critical ratio is 7.840. Therefore the hypothesis is supported. From the structural equation analysis, we found that all the hypothesized relationships are supported by the empirical data. 


\section{Discussion and Implications}

The aim of the present study is to identify success factors for e-service delivery. For doing that we used e-service quality and use as an antecedent of citizen satisfaction. Based on result of empirical analysis all three hypotheses have been accepted.

In this study, Citizen Satisfaction was considered as an indicator of success of government e-tax service delivery, the assumption being that if citizens are satisfied with using this service, then that implies the service is successful. From the analysis of data, it was found that the variance explained by factors leading to citizen satisfaction is $43 \%$. Previous studies considered user satisfaction as a success measure in information system success, e-commerce success, and Web site success (DeLone \& McLean, 1992, 2004; Seddon and Kiew, 1996; Rai, 2002; Crowston et al., 2006).

We found e-service quality has a relation with citizen satisfaction considering four dimensions of service quality. Previous literature also suggested that Service quality is important antecedent to user satisfaction (Kettinger and Lee, 1994, 1997; Pitt et al., 1995; Caruana, 2002; Cronin and Taylor, 1992; Grönroos, 1984; Johnston, 1997).These four dimensions are efficiency, privacy, responsiveness and web assistance That means citizens consider these as important factors when they are using government e-services. Efficiency, responsiveness and web assistance are more important compared to privacy in determining e-service quality. Citizens are more concerned about how effectively and efficiently they can use this kind of website, what kind of support they can receive when they are filing their tax return. Privacy dimension was not found to be a very important. A reason behind this could be since this is a government website, the citizen believes that a government organization will maintain citizens' privacy and will not abuse citizen information for any commercial purposes, as might be the case for an industrial or commercial organization. According to the DeLone McLean IS success model, use is an important dimension of success and we also found evidence of it from our empirical data analysis. According to the analysis of empirical data we found the relationship between usage and satisfaction. That means increase usage of the system will also increase the level of citizen satisfaction.

The first and foremost contribution of this study is identifying success factors of government e-service delivery that is developed in the context of the e-tax filing system in Sweden. Secondly, the result indicates that information system (IS), ecommerce, and marketing theory are applicable in the government to citizen (G2C) area; more specifically, government e-tax service delivery.

These findings have led this research to stress the need to focus on the factors that work behind the scenes in the satisfactory provisioning of this service to citizens as well as the need and means for measuring such satisfaction. Along with the theoretical contributions, there are some practical implications of the research findings. It is important for the practitioner such as tax authorities and other government organizations that are involved with the delivery of e-services, to be aware of the factors that contribute towards the future maintenance of the quality of the e-government services. The results can help the tax authority to identify the key quality criteria for the e-tax service web sites that are valued by citizens. The results will also help the tax authority to understand the key issues that influence citizens' needs and level of satisfaction with this service. 


\section{Limitations and Suggestions for Future Research}

Based on our empirical analysis we found satisfaction to be an important factor for success and satisfaction is determined by service quality and uses of the services. But results also indicate that there are additional factors that determine satisfaction since variance explained by factors leading to citizen satisfaction is $43 \%$. The study only included service quality; further study can explore other quality dimensions- system quality, information quality and other success factors. Tax payment was the study context, but other studies can be done in the context of other web based government services like e-health, renewing driver's license, voting on the Internet etc.

\section{References}

Bigné, E., Moliner, M.A., Sánchez, J.: Perceived quality and satisfaction in multiservice organisations: the case of Spanish public services. Journal of Services Marketing 17(4), 420 $442(2003)$

Blakeley, C.J., Matsuura, J.H.: E-government: An engine to power e-commerce development. In: Proceedings of the 2nd European conference on e-government, Dublin, Ireland, pp. 39-48 (2001)

Booze Allen Hamilton consulting report on world-wide best practice in e-government, commissioned by the UK Cabinet Office (2005)

Buckley, J.: E-service quality and the public sector. Managing Service Quality 13(6), 453-462 (2003)

Burton-Jones, A., Straub, D.W.: Reconceptualizing System Usage: An Approach and Empirical Test. Information Systems Research 17(3), 228-246 (2006)

Caruana, A.: Service Loyalty-The effects of service quality and the mediating role of customer satisfaction. European Journal of Marketing 36(7/8), 811-828 (2002)

Centeno, C., Van Bavel, R., Burgelman, J.C.: A Prospective View of e-Government in the European Union. The Electronic Journal of e-Government 3(2), 59-66 (2005)

Collier, J.E., Bienstock, C.C.: Measuring Service Quality in E-Retailing. Journal of Service Research 8, 260 (2006)

Connolly, R., Bannister, F.: eTax Filing \& Service Quality: The Case of the Revenue Online Service. In: Proceedings of World Academy of Science, Engineering and Technology, April 2008, vol. 28 (2008) ISSN: 1307-6884

Cronin, J.J., Brady, M.K., Hult, T.M.: Assessing the Effects of Quality, Value, and Customer Satisfaction on Consumer Behavioral Intentions in Service Environments. Journal of Retailing 76(2), 193-218 (2000) ISSN: 0022-4359

Cronin, J.J., Taylor, S.A.: Measuring service quality: a re-examination and extension. Journal of Marketing 56(3), 55-69 (1992)

Crowston, K., Howison, J., Annabi, H.: Information systems success in free and open source software development: Theory and measures. Software Process: Improvement and Practice (Special Issue on Free/Open Source Software Processes) (in press)

DeLone, W.H., McLean, E.R.: Measuring e-Commerce Success: Applying the DeLone \& McLean Information Systems Success Model. International Journal of Electronic Commerce 9(1), 31-47 (2004)

DeLone, W.H., McLean, E.R.: Information system Success: The quest for dependent variable. Information system research 3(1) (1992) 
Eckerlund, I., Eklöf, J.A., Nathorst-Böös, J.: Patient satisfaction and priority setting in ambulatory health care. Total Quality Management 11(7), 967-978 (2000)

Goodhue, D.L., Thompson, R.L.: Task-Technology Fit and Individual Performance. MIS Quarterly 19(2), 213-236 (1995)

Grönroos, C.: A service quality model and its market implications. European Journal of Marketing 18(4), 36-44 (1984)

Guo, X., Lu, J., Raban, R.: An Assessment of the Characteristics of Australian Government Eservice Websites. Collaborative Electronic Commerce Technology and Research (2002)

Hair, J.F., Babin, B., Money, A.H., Samouel, P.: Essentials of Business Research. John Wiley \& Sons, Inc., Chichester (2007)

Hazlett, S.A., Hill, F.: E-government: the realities of using IT to transform the public sector. Managing Service Quality 13(6), 445-452 (2003)

Janssens, W., Wijnen, K., Pelsmacker, P.D., Kenhove, P.V.: Marketing Research with SPSS. Prentice-Hall, Englewood Cliffs (2008)

Johnston, R.: Identifying the critical determinant of service quality in retail banking: importance and effect. International Journal of bank marketing 15(4), 111-116 (1997)

Kanji, G.K., A. bin Tambi, A.M.: Total quality management in UK higher education institutions. Total Quality Management 10(1), 129-153 (1999)

Kaylor, C., Deshazo, R., Van Eck, D.: Gauging e-government: a report on implementing services among American cities. Government Information Quarterly 18, 293-307 (2001)

Kelly, J.M., Swindell, D.: Service Quality Variable Across Urban Apace: First Steps Toward a Model of Citizen Satisfaction. Journal of urban affairs 24(3), 271-288 (2002)

Kettinger, W.J., Lee, C.C.: Perceived service quality and user satisfaction with the information services function. Decision Sciences 25(5/6), 737-766 (1994)

Lihua, W., Zheng, Q.: Internet use and e-government performance: a conceptual Model. In: Ninth Pacific Asia Conference on Information Systems, PACIS, Bangkok, Thailand (2005)

Li, Y.N., Tan, K.C., Xie, M.: Measuring web-based service quality. Total Quality Management 13(5), 685-700 (2002)

Liu, C., Arnett, K.P.: Exploring the Factors Associated with Website Success in the Context of Electronic Commerce. Information \& Management 38, 23-33 (2000)

Luarn, P., Lin, H.: A customer loyalty model for e-service context. Journal of Electronic Commerce Research 4(4) (2003)

Molla, A., Licker, P.S.: E-Commerce system success: An attempt to extend and respecify the DeLone \& McLean model of IS success. Journal of Electronic Commerce Research 2(4) (2001)

Parasuraman, A., Berry, L.L., Zeithaml, V.A.: Refinement and Reassessment of the SERVQUAL Scale. Journal of Retailing 67(4), 420-450 (1991)

Parasuraman, A., Zeithaml, V.A., Malhotra, A.: E-S-QUAL: A Multiple-Item Scale for Assessing Electronic Service Quality. Journal of Service Research 7(3), 213-233 (2005)

Parasuraman, A., Zeithaml, V.A., Berry, L.L.: SERVQUAL: a multiple item scale for measuring consumer perceptions of service quality. Journal of Retailing 64, 12-40 (Spring 1988)

Peters, R.M., Janssen, M., Van Engers, T.M.: Measuring e-Government Impact: Existing practices and shortcomings. In: ICEC'04, sixth International Conference on Electronic Commerce (2004)

Pitt, L.F., Watson, R.T., Kavan, C.B.: Service Quality: A measure of information systems effectiveness. MIS Quarterly (June 1995)

Rai, A., Lang, S.S., Welker, R.B.: Assessing the Validity of IS Success Models: An Empirical Test and Theoretical Analysis. Information Systems Research 13(1), 50-69 (2002) 
Ray, S., Rao, V.: Evaluating Government Service: A customers' Perspective of e-Government. In: Proceedings of the 4th European Conference on E-Government, Dublin, Ireland, June 1718 (2004)

Roca, C.J., Chiu, C.-M., Martinez, F.J.: Understanding e-learning continuance intention: An extension of the Technology Acceptance Model. International Journal of Human-Computer Studies 64, 683-696 (2006)

Ruyter, K.D., Bloemer, J., Peeters, P.: Merging service quality and service satisfaction. An empirical test of an integrative model. Journal of Economic Psychology 18(4), 387-406 (1997)

Seddon, P.B.: A Respecification and Extension of the DeLone and Mclean Model of IS Success. Information System Research 8(3) (1997)

Seddon, P.B., Kiew, M.Y.: A partial test and development of Delone and Mclean's model of is success. Australian Journal of Information system (AJIS) 4(2) (1996)

Spreng, R.A., Mackoy, R.: An empirical examination of a model of perceived service quality and satisfaction. Journal of Retailing 72(2), 201-214 (1996)

Thompson, R.L., Higgins, C.A., Howell, J.M.: Towards a Conceptual Model of Utilization. MIS Quarterly 15(1), 125-143 (1991)

Wang, Y.S., Wang, H.Y., Shee, D.Y.: Measuring e-learning systems success in an organizational context: Scale development and validation. Computers in Human Behavior 23, 1792-1808 (2007)

Wang, L., Bretschneider, S., Gant, J.: Evaluating Web-based e government services with a citizen-centric approach. In: Proceedings of the 38th Hawaii International Conference on System Sciences 2005 (2005)

Welch, E.W., Hinnant, C.C., Moon, J.M.: Linking Citizen Satisfaction with E-Government and Trust in Government. Journal of Public Administration Research and Theory 15(3) (2004)

Hu, Y., Xiao, J., Pang, J., Xie, K.: A research on the framework of e-government project success. In: Seventh international conference on electronic commerce, ICEC, Xian, China (2005)

Zeithaml, V.A., Parasuraman, A., Malhotra, A.: A Conceptual Framework for Understanding eService Quality: Implications for Future Research and Managerial Practice: Working paper, Marketing Science Institute, Report Number 00-115, Cambridge, MA (2000)

Zeithaml, V.A., Parasuraman, A., Malhotra, A.: Service quality delivery through web sites: a critical review of extant knowledge. Journal of the academy of marketing science 30(4) (2002) 